\title{
Influence of Sodium Chloride Induce Salinity on Growth, Yield and Juice Quality of Promising Sugarcane Genotypes
}

\author{
Smita Kumari and C. K. Jha* \\ Sugarcane Research Institute, Dr. Rajendra Prasad Central Agricultural University, \\ Pusa (Samastipur) Bihar- 848 125, India \\ *Corresponding author
}

\begin{tabular}{|l}
\hline K e y w o r d s \\
Salt stress, Yield, \\
Juice Quality, \\
Genotype, \\
Sugarcane
\end{tabular}

\section{Keywords}

Salt stress, Yield Juice Quality, Genotype Article Info

Accepted: Available Online: 20 June 2018

\section{A B S T R A C T}

The experiment was conducted to study the effect of salinity levels (ECe value $0,2.5$ and $5.0 \mathrm{dSm}^{-1}$ ) on sugarcane genotypes (CoP 9702, CoP 112, BO 154, BO 153 and CoP 9301) under $\mathrm{NaCl}$ induced salt stress condition in glasshouse at Sugarcane Research Institute, Pusa, Bihar. The increasing salinity levels from 0 to $5 \mathrm{dSm}^{-1}$ ECe significantly decreased germination, plant height and plant population indicating stunting of growth under salt stress condition. The ECe value of $5.0 \mathrm{dS} \mathrm{m}^{-1}$ leads to overall reduction in germination $(30.28 \%)$, cane weight $(25.72 \%)$ cane yield $(28.05 \%)$ and sugar yield $(33.25 \%)$ over control. Among sugarcane genotypes, BO154 followed by CoP112 recorded significantly superior as compared to rest of the genotypes in terms of growth parameters and yield. The genotypes, BO154 attained maximum germination, plant height and cane yield followed by $\mathrm{CoP} 112$ and lowest in COP 9301. The reduction in cane yield among the genotypes were in order of $\mathrm{BO} 154>\mathrm{CoP} 112>\mathrm{CoP} 9702>\mathrm{BO} 153>\mathrm{CoP} 9301$. The value of brix, pol and juice recovery significantly decreased with increasing level of salinity, however purity coefficient remains unaffected. The mean sugar yield increased by $9.66 \%$ in BO 154 and $5.44 \%$ in CoP 112 over BO 153. Sugar yield, a function of cane yield and exhibited similar trend of cane yield. The salt stress caused increased concentration and uptake of $\mathrm{Na}^{+}$and $\mathrm{Na}+/ \mathrm{K}+$ ratio in sugarcane leaf. BO 154 and CoP 112 performed better by maintaining lower $\mathrm{Na}^{+} / \mathrm{K}^{+}$ratio. The increase in $\mathrm{Na}^{+} / \mathrm{K}^{+}$ratio was observed in salt sensitive genotypes viz. CoP 9301 and $\mathrm{BO}$ 153. The $\mathrm{pH}$ and EC of post soil increased while organic carbon of soil decreased significantly with increasing level of salinity. The $\mathrm{Cl}^{-}$content of soil varied significantly $\left(16.54-26.67 \mathrm{mel}^{-1}\right)$ due to salinity. Among sugarcane genotypes BO154, followed by CoP112 performed well in terms of sugar and cane yield under influence of salt stress and it may be grown as salt tolerant genotype in agro-climatic conditions of North Bihar.

\section{Introduction}

Sugarcane is grown extensively in tropical and sub-tropical regions of India and plays a pivotal role in both agricultural and industrial economy of the country. In India, area under sugarcane hovers around 5.0 million hectares, which is around $3 \%$ of the gross cultivable area in India with an annual production of 366.80 million tonnes and productivity of 63.7 tonnes per hectare. The sugarcane productivity remained low, primarily due to the cultivation 
of cane in to relatively less fertile marginal soils, which are characterized by various stresses occurring during the crop growth. Soil salinity limits the sugarcane production in considerable area of Bihar. The problem of salinity in combination of other abiotic stresses is known to influence the cane yield in both tropical and subtropical climate. The growth and yield components of sugarcane were reduced under saline stress as compared to the respective attributes in normal soil (Thakur et al., 2010 and Singh et al., 2015). Salt affected soils exist across the length and breadth of India covering 16 States/ Union Territories with a total area of 7.0 mha. In Indo-gangatic alluvial plains, about 2.5 million ha are salt affected, out of which a sizeable area lies under salinity. In absence of detailed soil survey, Bihar is having 4 lakh ha of sodic soil, which either produce very low crop yield or no yield.

The salt affected soil in the state of Bihar is widespread in the northern flood plain of the Ganges covering parts of East and West Champaran, Muzaffarpur, Gopalganj, Siwan and Chhapra districts. Area of such land is increasing year by year due to faulty irrigation management, high water table and drainage problems. These soils have $\mathrm{pH}$ of saturation paste (pHS) less than 8.5, ESP less than 15, and ECe more than $4 \mathrm{dS} \mathrm{m}^{-1}$ at $25^{\circ} \mathrm{C}$. However, based on the Indian experience, saline soils having pHs less than 8.2, ECe more than $4 \mathrm{dS} \mathrm{m}^{-1}$ and preponderance of chlorides and sulphates of $\mathrm{Na}, \mathrm{Ca}$, and $\mathrm{Mg}$. Excess amount of salt in the soil adversely affects plant growth and development. High salt concentration decreases the potential of soil solution creating a water stress in plants that also causes severe toxicity, salt stress and dehydration stress. Under saline soil conditions, sugarcane plants are unable to absorb water and minerals from the soil because of osmotic imbalance. A high degree of salinity results in to physiological, biochemical, molecular and genetical effects (Yusuf et al., 2010).

The Sugarcane Research Institute, Pusa developed several promising genotypes of sugarcane. The evaluation of genotypes is necessary for its performance in saline soil to increase sugarcane productivity in agro climatic condition of Bihar. Adoption of tolerant sugarcane genotype would be one of the best ways to reduce the loss in cane productivity in salt affected soils. Reclamation of saline soils is time consuming and costly affair. Therefore, it is important to evaluate the affect of salinity and screening of sugarcane genotypes to break the existing plateau of cane productivity fom such marginal lands. The tolerant genotypes are being used to counteract salinization effects and to improve productivity of such marginal lands. These considerations prompted to undertake the present investigation.

\section{Materials and Methods}

\section{Experimental Site}

The present investigation was undertaken with an aim to study the effect of salinity levels on productivity and juice quality of sugarcane genotypes during 2016-17, at Sugarcane Research Institute, RPCAU, Pusa, Bihar. The site has hot and humid summers and too cold winters with average rainfall of $1200 \mathrm{~mm}$ of which $75 \%$ received during the monsoon period (mid June - mid September). The mean annual temperature is $24.5^{\circ} \mathrm{C}$ with maximum $38.6^{\circ} \mathrm{C}$ during April and minimum $7.4^{\circ} \mathrm{C}$ in January.

\section{Experimental Soil}

The soil of the experimental site belongs to order Entisol, suborder Fluvents and great group Ustifluvent. The experimental soil was sandy loam in texture with moderately 
alkaline $\mathrm{pH}$ (8.18), low in organic carbon $(0.45 \%)$, SAR (9.0) and EC $\left(0.27 \mathrm{dSm}^{-1}\right)$ and low in available N-P-K (234.3- 18.1-114.6 $\mathrm{kg} / \mathrm{ha}$ ). The $\mathrm{Fe}, \mathrm{Zn} \mathrm{Cu}$ and $\mathrm{Mn}$ content of initial soil was $8.79,0.79,1.02$ and $4.62 \mathrm{mg}$ $\mathrm{kg}^{-1}$ respectively.

\section{Experimental design and application of treatments}

The pot experiment was conducted with treatment consisted of three salinity levels $(0$, 2.5 and $5.0 \mathrm{dSm}-1)$ and five sugarcane genotypes developed by SRI, Pusa (CoP 9702, CoP 112, B.O. 154, B.O 153 and CoP 9301) with three replication in CRD. Soil sample (0$15 \mathrm{~cm}$ ) was collected from crop research farm, Pusa from medium upland and having uniform topography for filling of pot. The bulk samples were grouped in three separate parts for salinity development. The desired salinity levels were developed by mixing the suitable amount of $\mathrm{NaCl}$ in soil before filling the pot. The electrical conductivity of soil saturation extract (ECe) of $2.5 \mathrm{dSm}^{-1}$ and $5.0 \mathrm{dSm}^{-1}$ was developed after one week of incubation. The sugarcane genotypes were planted in cemented pit having capacity of $100 \mathrm{~kg}$ soil. NPK was applied as per recommendations (150-85-60). The one budded setts were planted after setts treatment. The salinity was maintained in salt treated pots during the experiment. Half of $\mathrm{N}$ was top dressed in two equal splits. The first top dressing was done after 60 days after planting and second at the time of earthing-up. All the standard agronomical practices were followed.

\section{Experimental observations and procedure}

The growth contributing characters and cane yield for each treatment were recorded. The leaf samples collected after harvest were analysed for $\mathrm{Na}$ and $\mathrm{K}$ using standard procedure. Soil samples $(0-15 \mathrm{~cm})$ were collected before initiation and after harvest of crop. The soil samples were analysed for $\mathrm{pH}$ and EC (Jackson 1973), organic carbon (Walklay and Black., 1934) and chloride in soil saturation extract (Richard 1954). The cane juice quality was determined using procedure outlined by Spencer and Meade (1964) and sugar yield was calculated. The data were analysed statistically.

\section{Results and Discussion}

\section{Effect on growth parameters}

\section{Germination}

The mean germination varied significantly and ranges from $41.61-54.21 \%$ due to salinity (Table 1). Maximum (30.28\%) reduction in germination was recorded at ECe $5.0 \mathrm{dSm}^{-1}$ levels of salinity as compared to control. The germination was delayed for a month due to salinity. The genotype BO 154 recorded significantly highest germination percentage (53.84\%) followed by CoP112 (50.53\%) as compared to CoP $9301(42.35 \%)$ and $\mathrm{CoP}$ 9702 (45.02\%). The genotypes BO 154 followed by CoP 112 establish better under saline soil condition and produces maximum plant population. There was inhibitory effect on germination of sugarcane genotypes at high salt concentration. Singh et al., (2003) and Wahid (2004) reported similar findings.

\section{Plant height}

The increasing salinity levels significantly decreased plant height (Table 1) indicating stunting of growth under salt stress condition. The sugarcane genotype BO154 attained maximum plant height followed by $\mathrm{CoP} 112$ and CoP 9702 at both the stages of plant growth. The sugarcane genotypes BO 154 followed by CoP 112 performing well under saline condition up to ECe $5.0 \mathrm{dSm}^{-1}$ levels of salinity. The lowest plant height was recorded in genotype $\mathrm{V}_{5}(\mathrm{CoP} 9301)$ at both the stages 
of plant growth. The performance of genotype CoP 9301 and BO 153 was significantly inferior and found at par at both the stages of plant growth. The data clearly indicated that sugarcane genotypes BO154 followed by Cp112 and CoP 9702 performing well under saline condition. Plant height is an important characteristic for assimilation of organic constituents.

The sugarcane genotypes attended the maximum height in saline soil indicated the adaptability and sustainability. The variation in plant height in different sugarcane genotypes might be because of injury to plant roots in rhizosphere by built of toxic ions and than their gradual accumulation in aerial parts cause damage to plant metabolism and reducing growth. Singh et al., (2002) and Singh et al., (2003) recorded similar observations. The salinity reduces growth through osmotic stress, increases cellular $\mathrm{Na}$ and $\mathrm{Cl}$ contents and exerts negative imbalance of $\mathrm{K}, \mathrm{Ca}$ and $\mathrm{NO}_{3}$ nutrition depending upon the stress severity (Flowers and Colmer, 2008).

\section{Effect on yield attributes and yield}

\section{Single cane weight}

The reduction in mean cane weight (Table 2) due to salinity at $2.5 \mathrm{dS} / \mathrm{m}$ and $5.0 \mathrm{dSm}^{-1}$ levels of salinity over control was to the extent of $12.64 \%$ and $25.72 \%$, respectively. The ECe value of $5.0 \mathrm{dS} \mathrm{m}^{-1}$ leads to overall reduction to the extent of $25.72 \%$ in single cane weight over control.

The highest cane weight was recorded in genotypes BO154 followed by CoP 112 and minimum in CoP 9301.The sugarcane genotype $\mathrm{BO} 154$ was found at par with $\mathrm{CoP}$ 112 and performance of these genotypes were superior over rest of the genotypes. Under salt stress condition reduction in cane weight in susceptible genotypes associated with more reduction in growth rate of sugarcane. Gomathi et al., (2014) and Singh et al., (2002) reported similar findings.

\section{Cane yield}

The cane yield (Table 2) of sugarcane significantly decreased with increasing level of salinity from 2.5 to $5.0 \mathrm{dSm}^{-1}$. The reduction in yield due to salinity at $2.5 \mathrm{dSm}^{-1}$ and $5.0 \mathrm{dSm}^{-1}$ over control was to the extent of $14.69 \%$ and $28.08 \%$, respectively. The mean cane yield varied from $3.17-4.06 \mathrm{Kg} \mathrm{pot}^{-1}$ due to salinity. Among genotypes mean cane yield varied significantly from $3.36-3.83 \mathrm{~kg} \mathrm{pot}^{-1}$. The genotype BO154, CoP 112 and CoP 9702 increased cane yield significantly as compared to BO153 and Cop 9301. The highest cane yield was recorded in genotype BO154 followed by $\mathrm{CoP} 112$ and minimum in $\mathrm{CoP}$ 9301. The sugarcane genotype BO154 was found at par with $\mathrm{CoP} 112$. The mean cane yield increased by $14.00 \%$ and $10.12 \%$ in genotypes BO 154 and CoP 112, respectively over CoP 9301.

The ECe value of $5.0 \mathrm{dSm}^{-1}$ leads to overall reduction in germination $(30.28 \%)$, single cane weight $(25.72 \%)$ and cane yield $(28.05$ $\%)$ over control. Excess salts adversely affect the growth and development of sugarcane crop which ultimate results in poor crop growth and cane yield. Unlike other crops, yield of sugarcane is directly related the vegetative growth which is main components for yield. The lower yield at salinity might be because of sugarcane shows a decline in growth and yield attributing characteristics. Akthar et al., (2003) reported that excess of soluble salts in root zone was inevitably taken up, which accumulate in the aerial parts and reduce growth and yield. Thakur et al., (2010) and Gomathi et al., (2014) reported varietal difference in terms of cane yield. Singh et al., (2015) also recorded similar findings. 
Table.1 Effect of salt stress on growth parameters of promising Sugarcane Genotypes

\begin{tabular}{|c|c|c|c|c|c|c|c|c|c|c|c|c|}
\hline \multirow[t]{2}{*}{ Treatments } & \multicolumn{3}{|c|}{ Germination (\%) } & \multirow[t]{3}{*}{ Mean } & \multirow{2}{*}{\multicolumn{3}{|c|}{$\begin{array}{l}\text { Plant height }(\mathrm{cm}) 120 \\
\text { DAP } \\
\text { Salinity level }\left(\mathrm{dSm}^{-1}\right)\end{array}$}} & \multirow[t]{3}{*}{ Mean } & \multicolumn{3}{|c|}{ Plant height (cm) 240 DAP } & \multirow[t]{3}{*}{ Mean } \\
\hline & \multicolumn{3}{|c|}{ Salinity level $\left(\mathrm{dSm}^{-1}\right)$} & & & & & & Saliı & level $(c$ & & \\
\hline Genotypes & Control & 2.5 & 5.0 & & Control & 2.5 & 5.0 & & Control & 2.5 & 5.0 & \\
\hline CoP 112 & 55.70 & 50.50 & 45.34 & 50.53 & 103.33 & 94.30 & 90.33 & 95.98 & 215.00 & 198.66 & 190.00 & 201.22 \\
\hline BO 154 & 66.50 & 50.83 & 44.20 & 53.84 & 106.30 & 96.30 & 94.33 & 98.97 & 233.33 & 201.33 & 185.00 & 206.55 \\
\hline Mean & 54.21 & 45.76 & 41.61 & & 101.19 & 93.36 & 88.94 & & 219.99 & 198.66 & 180.60 & \\
\hline Source & S & G & SXG & CV\% & S & G & SXG & $\mathrm{CV} \%$ & S & $\mathrm{G}$ & SXG & $\mathrm{CV} \%$ \\
\hline LSD $_{(0.05)}$ & 2.71 & 3.50 & NS & 7.71 & 3.06 & 3.95 & NS & 4.35 & 6.16 & 7.96 & NS & 4.14 \\
\hline
\end{tabular}

Note S-Salinity level, G-genotypes

Table. 2 Effect of salt stress on yield attributes and yields of promising sugarcane genotypes

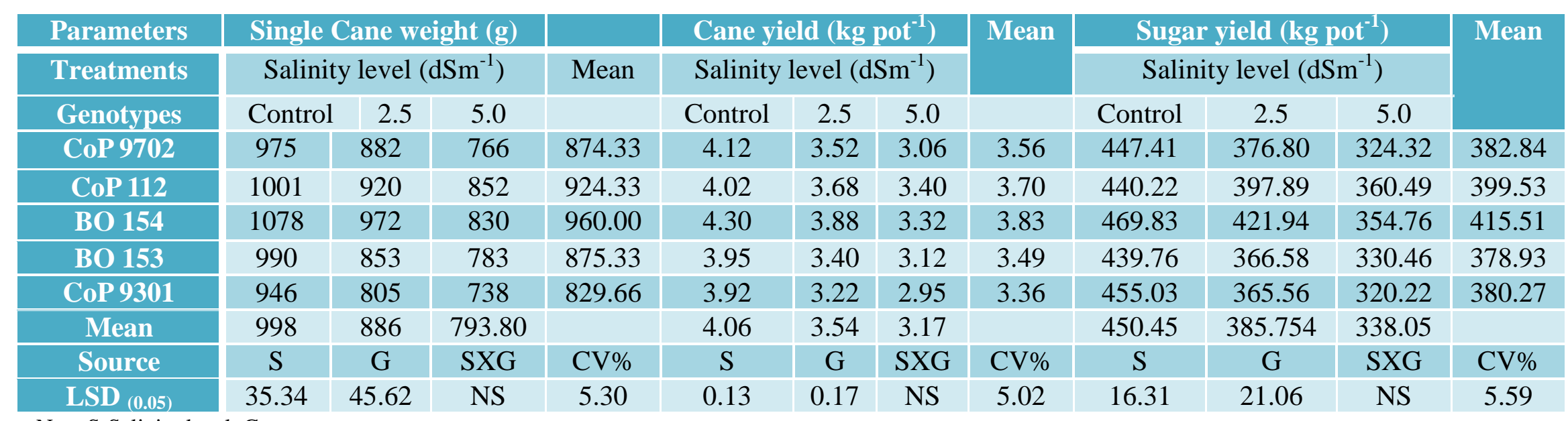

Note S-Salinity level, G-genotypes 
Table.3 Effect of salt stress on juice quality of promising sugarcane genotypes

\begin{tabular}{|c|c|c|c|c|c|c|c|c|c|c|c|c|}
\hline \multirow{3}{*}{$\begin{array}{l}\text { Parameters } \\
\text { Treatments } \\
\text { Genotypes } \\
\end{array}$} & \multicolumn{3}{|c|}{ Brix (\%) } & \multicolumn{4}{|c|}{ Pol $(\%)$} & \multirow[t]{3}{*}{ Mean } & \multirow{2}{*}{\multicolumn{3}{|c|}{$\begin{array}{l}\text { Purity (\%) } \\
\text { inity level }\left(\mathrm{dSm}^{-1}\right)\end{array}$}} & \multirow[t]{3}{*}{ Mean } \\
\hline & \multicolumn{3}{|c|}{ Salinity level $\left(\mathrm{dSm}^{-1}\right)$} & Mean & \multicolumn{3}{|c|}{ Salinity level $\left(\mathrm{dSm}^{-1}\right)$} & & & & & \\
\hline & Control & 2.5 & 5.0 & & Control & 2.5 & 5.0 & & Control & 2.5 & 5.0 & \\
\hline CoP 9702 & 18.20 & 17.93 & 18.00 & 18.04 & 15.83 & 15.60 & 15.52 & 15.65 & 86.96 & 87.03 & 87.30 & 87.09 \\
\hline CoP 112 & 18.30 & 18.16 & 17.83 & 18.09 & 15.93 & 15.76 & 15.46 & & & 86.76 & 86.90 & 86.90 \\
\hline BO 154 & 18.50 & 18.26 & 18.00 & 18.25 & 15.98 & 15.86 & 15.60 & 15.81 & 86.36 & 86.80 & 86.66 & 86.60 \\
\hline BO 153 & 18.46 & 18.16 & 17.80 & 18.14 & 16.17 & 15.73 & 15.45 & 15.78 & 87.60 & 86.50 & 86.80 & 86.96 \\
\hline CoP 9301 & 19.00 & 18.80 & 18.43 & 18.74 & 16.78 & 16.47 & 15.89 & 16.38 & 88.30 & 87.60 & 86.23 & 87.37 \\
\hline Mean & 18.49 & 18.26 & 18.01 & & 16.13 & 15.88 & 15.58 & & 87.25 & 86.93 & 86.77 & \\
\hline Source & $\mathrm{S}$ & $\mathrm{G}$ & $\mathrm{SXG}$ & CV\% & $\mathrm{S}$ & $\mathrm{G}$ & SXG & CV\% & $\mathrm{S}$ & $\mathrm{G}$ & SXG & $\mathrm{CV} \%$ \\
\hline LSD $_{(0.05)}$ & 0.22 & 0.28 & NS & 1.61 & 0.18 & 0.24 & NS & 1.56 & NS & NS & 1.05 & 0.69 \\
\hline
\end{tabular}

Note S-Salinity level, G-genotypes

Table.4 Effect of salt stress on Na concentration, its uptake and $\mathrm{Na} / \mathrm{K}$ ratio in leaf of promising sugarcane genotypes

\begin{tabular}{|c|c|c|c|c|c|c|c|c|c|c|c|c|}
\hline \multirow{3}{*}{$\begin{array}{l}\text { Parameters } \\
\text { Treatments } \\
\text { Genotypes }\end{array}$} & Na col & entrati & $(\%)$ & \multirow[t]{3}{*}{ Mean } & \multicolumn{3}{|c|}{$\mathrm{Na} / \mathrm{K}$ ratio } & \multirow[t]{3}{*}{ Mean } & \multirow{2}{*}{\multicolumn{3}{|c|}{$\begin{array}{l}\text { Na uptake }\left(\text { g pot }^{-1}\right) \\
\text { Salinity levels }\left(\mathrm{dSm}^{-1}\right)\end{array}$}} & \multirow[t]{3}{*}{ Mean } \\
\hline & \multicolumn{3}{|c|}{ Salinity levels $\left(\mathrm{dSm}^{-1}\right)$} & & \multicolumn{3}{|c|}{ Salinity levels $\left(\mathrm{dSm}^{-1}\right)$} & & & & & \\
\hline & Control & 2.5 & 5.0 & & Control & 2.5 & 5.0 & & Control & 2.5 & 5.0 & \\
\hline CoP 9702 & 0.045 & 0.070 & 0.090 & 0.068 & 0.050 & 0.080 & 0.118 & 0.082 & 0.69 & 0.92 & 1.04 & 0.98 \\
\hline CoP 112 & 0.043 & 0.070 & 0.086 & 0.066 & 0.048 & 0.078 & 0.108 & 0.078 & 0.65 & 0.97 & 1.10 & 1.03 \\
\hline BO 154 & 0.041 & 0.065 & 0.085 & 0.063 & 0.044 & 0.075 & 0.108 & 0.075 & 0.66 & 0.95 & 1.06 & 1.00 \\
\hline BO 153 & 0.048 & 0.076 & 0.096 & 0.073 & 0.054 & 0.088 & 0.125 & 0.089 & 0.71 & 0.97 & 1.13 & 1.05 \\
\hline CoP 9301 & 0.046 & 0.079 & 0.098 & 0.074 & 0.053 & 0.093 & 0.133 & 0.093 & 0.68 & 0.95 & 1.09 & 1.02 \\
\hline Mean & 0.045 & 0.072 & 0.091 & & 0.050 & 0.083 & 0.12 & & 0.68 & 0.95 & 1.08 & \\
\hline Source & S & G & SXG & $\mathrm{CV} \%$ & S & $\mathrm{G}$ & SXG & CV\% & S & G & SXG & $\mathrm{CV} \%$ \\
\hline LSD $_{(0.05)}$ & 0.002 & 0.003 & NS & 4.30 & 0.002 & 0.002 & NS & 3.25 & 0.026 & 0.034 & NS & 3.95 \\
\hline
\end{tabular}




\section{Int.J.Curr.Microbiol.App.Sci (2018) 7(6): 1366-1375}

Table.5 Effect of salt stress on physic-chemical properties of soil after sugarcane harvest

\begin{tabular}{|c|c|c|c|c|c|c|c|c|c|c|c|c|c|c|c|c|}
\hline \multirow{3}{*}{$\begin{array}{l}\text { Treatments } \\
\text { Genotypes }\end{array}$} & \multicolumn{3}{|c|}{ pH } & \multirow[t]{3}{*}{ Mean } & \multirow{2}{*}{\multicolumn{3}{|c|}{$\begin{array}{l}\text { ECe }\left(\mathrm{dSm}^{-1}\right) \\
\text { Salinity levels } \\
\left(\mathrm{ECe} \mathrm{dSm}^{-1}\right)\end{array}$}} & \multirow{3}{*}{ Mean } & \multirow{2}{*}{\multicolumn{3}{|c|}{$\begin{array}{l}\text { Organic Carbon } \\
\qquad(\%) \\
\text { Salinity levels } \\
(\text { ECe dSm }\end{array}$}} & \multirow{3}{*}{ Mean } & \multirow{2}{*}{\multicolumn{3}{|c|}{$\begin{array}{l}\mathrm{Cl}^{-} \text {content in soil } \\
\text { saturation extract } \\
(\mathrm{me} / \mathrm{l}) \\
\text { Salinity levels } \\
(\text { ECe dSm-1) }\end{array}$}} & \multirow[t]{3}{*}{ Mean } \\
\hline & \multicolumn{3}{|c|}{$\begin{array}{l}\text { Salinity levels } \\
\left(\mathrm{ECe} \mathrm{dSm}^{-1}\right)\end{array}$} & & & & & & & & & & & & & \\
\hline & Control & 2.5 & 5.0 & & \multirow{2}{*}{$\begin{array}{c}\text { Control } \\
0.27\end{array}$} & \multirow{2}{*}{$\begin{array}{c}2.5 \\
1.49\end{array}$} & \multirow{2}{*}{$\begin{array}{c}5.0 \\
2.95\end{array}$} & & \multirow{2}{*}{$\begin{array}{c}\text { Control } \\
0.46\end{array}$} & \multirow{2}{*}{$\begin{array}{c}2.5 \\
0.44\end{array}$} & \multirow{2}{*}{$\begin{array}{c}5.0 \\
0.40\end{array}$} & & \multirow{2}{*}{\begin{tabular}{|c|} 
Control \\
16.80
\end{tabular}} & \multirow{2}{*}{$\begin{array}{c}2.5 \\
21.50\end{array}$} & \multirow{2}{*}{$\begin{array}{c}5.0 \\
26.40\end{array}$} & \\
\hline CoP 9702 & 8.20 & 8.23 & 8.32 & 8.25 & & & & 1.57 & & & & 0.43 & & & & 21.56 \\
\hline CoP 112 & 8.17 & 8.27 & 8.38 & 8.27 & 0.34 & 1.73 & 3.11 & 1.72 & 0.49 & 0.43 & 0.38 & 0.43 & 16.50 & 21.83 & 26.90 & 21.74 \\
\hline BO 154 & 8.21 & 8.25 & 8.36 & 8.27 & 0.28 & 1.46 & 3.01 & 1.58 & 0.48 & 0.42 & 0.41 & 0.43 & 16.25 & 21.65 & 26.80 & 21.57 \\
\hline BO 153 & 8.12 & 8.19 & 8.32 & 8.21 & 0.32 & 1.55 & 2.88 & 1.58 & 0.46 & 0.44 & 0.37 & 0.42 & 16.45 & 21.80 & 26.74 & 21.66 \\
\hline CoP 9301 & 8.18 & 8.29 & 8.40 & 8.29 & 0.36 & 1.62 & 3.08 & 1.68 & 0.49 & 0.45 & 0.39 & 0.44 & 16.70 & 21.40 & 26.50 & 21.53 \\
\hline Mean & 8.17 & 8.24 & 8.35 & & 0.31 & 1.57 & 3.00 & & 0.47 & 0.43 & 0.39 & & 16.54 & 21.63 & 26.67 & \\
\hline Source & S & G & SXG & $\mathrm{CV} \%$ & $\mathrm{~S}$ & $\mathrm{G}$ & SXG & $\mathrm{CV} \%$ & $\mathrm{~S}$ & G & SXG & CV\% & $\mathrm{S}$ & G & SXG & $\mathrm{CV} \%$ \\
\hline $\mathrm{LSD}_{(0.05)}$ & 0.015 & NS & NS & 0.24 & 0.017 & NS & NS & 1.46 & 0.008 & NS & NS & 5.95 & 1.05 & NS & NS & 9.62 \\
\hline
\end{tabular}

Note: S-Salinity level, G-genotypes 


\section{Sugar yield}

The reduction in mean sugar yield (Table 2) by $16.75 \%$ and $33.25 \%$ was observed due to salinity level of 2.5 and $5.0 \mathrm{dSm}^{-1}$, respectively, over control. Among sugarcane, genotypes BO 154 recorded significantly highest sugar yield followed by CoP112 and lowest in BO 153. The mean sugar yield increased by $9.66 \%$ in BO 154 and $5.44 \%$ in CoP 112 over BO 153. Sugar yield, a function of cane yield and exhibited similar trend of cane yield. The higher cane yield resulted in higher sugar yield. Excess salts adversely affect the growth and development of sugarcane crop which ultimate results in poor sugar recovery. Gomathi et al., (2014) reported similar findings.

\section{Effect on brix, pol and purity coefficient}

The data on juice quality parameters viz. brix, pol and purity coefficient has been presented in table 3 . The value of brix in sugar cane juice significantly decreased with increasing level of salinity from 2.5 to $5.0 \mathrm{dSm}^{-1}$. The brix of cane juice was in order of control $(18.49 \%)>2.5 \mathrm{dSm}^{-1}(18.26 \%)$ and $5.0 \mathrm{dSm}$ ${ }^{1}(18.01 \%)$ salinity. The brix of sugarcane genotypes CoP 9301 was significantly higher (18.74\%) followed by the genotype BO154 $(18.25 \%)$ than the rest of the sugarcane genotypes.

The osmotic component of $\mathrm{NaCl}$ mainly appeared to affect the transport of sucrose to stalks followed by stimulated sucrolytic activity in the internodes (Wahid 2004). Among salinity level maximum pol was recorded in control (16.14\%) and it's decreased with increasing ECe at $2.5 \mathrm{dSm}^{-1}$ $(15.88 \%)$ and $5.0 \mathrm{dSm}^{-1}(15.58 \%)$. Pol of sugarcane genotypes $\mathrm{CoP} 9301$ was significantly higher $(16.38 \%)$ than rest of the sugarcane genotypes. The genotypes BO153 (15.78\%), CoP $112(15.72 \%)$ and CoP 9702 were recorded lower sucrose content. Interaction between salinity level and genotypes was found non-significant. Similar findings were reported by Gomathi and Thandapani, (2005).

\section{Na concentration, uptake and $\mathrm{Na}^{+} / \mathrm{K}^{+}$ratio in plant}

The $\mathrm{Na}$ concentration and its uptake by sugarcane plant at harvest stage significantly increased with increasing salinity being highest in $5.0 \mathrm{dSm}^{-1}$ salinity as compared to control (Table 4). Among sugarcane genotypes, BO154 followed by CoP 112 and CoP 9702 recorded lower $\mathrm{Na}$ concentration as compared to other genotypes. The concentration of $\mathrm{Na}$ in cane leaf was significantly low in BO154 (0.063\%), CoP $112(0.066 \%)$ and $\mathrm{CoP} 9702(0.068 \%)$ as compared to BO153 and CoP 9301. The result indicated that BO154 showed least accumulation of $\mathrm{Na}$ in the leaf at grand growth stage. The highest $\mathrm{Na}$ accumulation in cane leaf was observed in genotype $\mathrm{CoP} 9301$ followed by BO 154 indicating susceptibility of these genotypes against toxic ions resulted in poor performance in terms of yield and quality. The mean uptake of $\mathrm{Na}$ varied $(0.68$ $1.08 \mathrm{~g} / \mathrm{pot}$ ) significantly due to salinity.

Among sugarcane genotype BO 153 recorded highest Na uptake and lowest in Cop 9702. The higher concentration in plant leads to higher uptake of $\mathrm{Na}$. Under salt stress $\mathrm{Ca}^{2+}$ promotes $\mathrm{K}^{+}$, and inhibits $\mathrm{Na}^{+}$uptake, thus maintaining high $\mathrm{Na}^{+} / \mathrm{K}^{+}$ratios that counteract the reduction in plant growth caused by salinity stress. Salt induced accumulation of toxic elements viz., $\mathrm{Na}$ was enhanced in susceptible genotypes. The resistant genotypes viz. BO 154 and CoP 112 performed better by maintaining lower $\mathrm{Na}^{+} / \mathrm{K}^{+}$ratio. The increase in $\mathrm{Na}^{+} / \mathrm{K}^{+}$ratio was observed in sensitive genotypes viz. CoP 9301 and BO 153 (Gracia and Medina, 2013). 


\section{Effect on soil properties}

The soil physico-chemical properties viz. $\mathrm{pH}$, ECe and organic carbon content of postharvest soil presented in table 5. The data indicated that $\mathrm{pH}$ and ECe of soil increased while organic carbon of soil decreased significantly with increasing level of salinity. The mean $\mathrm{pH}$ value varied from (8.18 to 8.36), ECe (0.33 to $\left.3.01 \mathrm{dSm}^{-1}\right)$ and organic carbon from ( 0.39 to $0.47 \%)$ due to salinity. It was also observed that salinity of soil decreased at harvest stage over the initial value. Among genotypes the $\mathrm{pH}, \mathrm{EC}$ and organic carbon were fond non-significant. The $\mathrm{Cl}^{-}$content of saturation extract of soil varied significantly due to salinity and ranges from 16.54 - $26.67 \mathrm{mel}^{-1}$. The data indicated that increasing salinity increased $\mathrm{Cl}^{-}$content of post-harvest soil. The salinity resulted in accumulation of these toxic ions in soil. The increased $\mathrm{Cl}^{-}$ions due to salinity adversely affected the growth of sugarcane plant. The organic carbon content of soil reduced due to salinity to the extent of $20.51 \%$ over control. The overall data indicated that salinity build up resulted in increased $\mathrm{pH}$, electrical conductivity and $\mathrm{Cl}^{-}$content of post-harvest soil. The addition of salt $\mathrm{NaCl}$ leads to reduction in organic carbon content and create unfavourable soil environment for plant growth. Saline soils are generally low in organic matter and adversely affect the solubility and availability of nutrients (Takkar and Mishra, 2004 and Hossain et. al., 2015).

Based on above findings it may be concluded that there was overall reduction in germination $(30.28 \%)$, cane weight $(25.72 \%)$ cane yield $(28.05 \%)$ and sugar yield $(33.25 \%)$ at ECe value $5.0 \mathrm{dS} / \mathrm{m}$ over control. Among sugarcane genotypes, BO154 followed by $\mathrm{CoP} 112$ recorded significantly superior as compared to rest of the genotypes and maintained lower $\mathrm{Na}^{+} / \mathrm{K}^{+}$ratio. The increase in $\mathrm{Na}^{+} / \mathrm{K}^{+}$ratio was observed in salt sensitive genotypes viz. CoP 9301 and BO 153. The sugarcane genotypes BO154 produced highest cane and sugar yield at all salinity levels followed by $\mathrm{CoP} 112$ as compared to other genotypes indicating that BO 154 and CoP 112 genotypes may be grown as moderately salt tolerant varieties under agro-climatic conditions of North Bihar.

\section{References}

Akhtar, Shamshad, Wahid, Abdul and Rasul, Ejaj. 2003. Emergences growth and nutrient composition of sugar cane sprout under $\mathrm{NaCl}$ Salinity. Biological Planetarium 46: 113-116.

Flowers, Timothy. J., and Colner, Timothy, D. 2008. Salinity tolerance in halophytes. New Phytotologogi. 179 (4): 945-963.

Gomathi, R., and Dhandapani, T. 2005. Salt stress in relation to nutrient accumulation and quality of sugarcane genotypes. Sugar Technology 7: 39-47.

Gomathi, R., and Thandapani, P. 2014. Influence of Salinity Stress on Growth Parameters and Yield of Sugarcane. IOSR Journal of Pharmacy and Biological Science. 9(3): 28-32.

Gracia, M., and Medina, E.2013. Effect of salt stress on salt accumulation in roots leaves of two sugarcane genotypes differing in salinity tolerance. Journal of Tropical Agriculture 51 (1-2):15-22.

Hossain, Nazmul, Muhammad, Muhibbullah, Barkat Ali, Kazi Md. and Molla, Morshed, Hossan. 2015. Relationship between soil salinity and physicochemical properties of paddy field soils of Jhilwanja. Union, Coxs Bazar, Bangladesh. Journal of Agricultural Science. 710: 166-180.

Jackson, M. L., 1973. Soil Chemical Analysis. Printice Hall, India Pvt. Ltd., New Delhi. 
Richards, LA (1954). Diagnosis and improvement of saline and alkali soil. USDA, Handbook No. 60.

Singh, J. R. P., Kamat, D. N. and Kumar, A. 2002. Variability in sugarcane under saline condition. Indian sugar. 52(3):265-267.

Singh, P.K., Sanjeev Kumar and Singh, J. 2003. Effect of salinity on inter specific hybrids of sugarcane (Saccharum spp). Co-operative Sugar 35(2):129-132.

Singh, S.P., Singh, R.P., Shahi, V., and Sharma, B.L. 2015. Effect of salinity on growth, yield and quality of sugarcane. Indian Journal of Sugarcane Technology. 30(2): 86-88.

Spencer, G.L., and Meade, G.P. 1964. Sugarcane handbook. John Wiley and Sons, London.

Takkar, P., and Mishra, B. 2004. Nutrients constraints and associated affect hindering crop growth in sodic soils. Proc. International Symposium on
Sustainable Management of Sodic Lands Lucknow, India, 37-39.

Thakur, S.K., Jha, C.K., and Paswan, S. 2010. Effect of salinity on germination, cane yield, uptake and juice quality of sugarcane genotypes. Environment and Ecology. 28(1A): 315-318.

Wahid, A., 2004. Analysis of toxic and osmotic effects of sodium chlioride on leaf growth and economic yield of sugarcane. Botanical Bulletin of Academia Sinica. 45: 133-141.

Walkely, A. J., and Black, C. A. 1934. Estimation of soil organic carbon by the chromic acid titration method. Soil Science. 37: 259-260.

Yusuf, B. S., Liu, L.Y., Nguyen, N. T., Masaoka, and Saneoka, H. 2010. Heritability $\mathrm{NaCl}$ comparative studies in salinity tolerance between New Zealand spinach (Tetrogoniatte tragonioides) and chard (Beta vulgaris) to salt stress. Agricultural Journal. 5: 19-40.

\section{How to cite this article:}

Smita Kumari and Jha C. K. 2018. Influence of Sodium Chloride Induce Salinity on Growth, Yield and Juice Quality of Promising Sugarcane Genotypes. Int.J.Curr.Microbiol.App.Sci. 7(06): 1366-1375. doi: https://doi.org/10.20546/ijcmas.2018.706.161 